\title{
CHARACTERIZATION OF THE IMAGINAL REPRODUCTIVE DIAPAUSE OF Oebalus poecilus (DALLAS) (HEMIPTERA: PENTATOMIDAE)
}

\author{
SANTOS, R. S. S., ${ }^{1}$ REDAELLI, L. R.. ${ }^{1}$ DIEFENBACH, L. M. G., ${ }^{1}$ \\ ROMANOWSKI, H. P. ${ }^{1}$ and PRANDO, H. F. ${ }^{2}$ \\ ${ }^{1}$ UFRGS, PPG Fitotecnia, Av. Bento Gonçalves, 7712, CEP 91540-000, Porto Alegre, RS \\ ${ }^{2}$ Epagri/Estação Experimental de Itajaí, C.P. 277, CEP 88301-970, Itajaí, SC \\ Correspondence to: Régis Sívori Silva dos Santos, UFRGS, Av. Bento Gonçalves, 7712, CEP 91540-000, \\ Porto Alegre, RS, e-mail: poecilus@bol.com.br \\ Received June 5, 2002 - Accepted November 13, 2002 - Distributed November 30, 2003
}

(With 4 figures)

\begin{abstract}
The state of development of the internal reproductive organs of male and female Oebalus poecilus (Dallas) as well as the body fat amount in the abdominal cavity during hibernation, of individuals sampled in bamboo litter in Eldorado do Sul $\left(30^{\circ} 02^{\prime} \mathrm{S}\right.$ and $\left.51^{\circ} 23^{\prime} \mathrm{W}\right)$, RS, Brazil was investigated. Females and males showed the abdominal cavity filled with body fat in the beginning of the hibernation phase. The decrease in fat reserve level occurred from August on for males and from October on for females. Ovaries and testis doubled in length and tripled in width from immature to the reproductive phase. Male sexual maturation occurred in the hibernation sites while for females it occurred later on outside of the sites. Reproductive organ immaturity and abdominal body fat hypertrophy characterized the diapause of $O$. poecilus.
\end{abstract}

Key words: overwintering, small rice stink bug, reproductive organs.

\section{RESUMO}

\section{Caracterização da diapausa imaginal reprodutiva de Oebalus poecilus (Dallas) (Hemiptera: Pentatomidae)}

Descreveu-se o estado de desenvolvimento dos órgãos internos de reprodução de fêmeas e machos de Oebalus poecilus (Dallas) e avaliou-se o conteúdo de corpos gordurosos contidos na cavidade abdominal, durante o período de hibernação, em indivíduos amostrados em folhedo de bambu, em Eldorado do Sul $\left(30^{\circ} 02^{\prime} \mathrm{S}\right.$ e $\left.51^{\circ} 23^{\prime} \mathrm{W}\right)$, RS, Brasil. No início da fase de hibernação, a cavidade abdominal de fêmeas e machos está repleta de reservas em forma de corpos gordurosos. A redução nos níveis de reservas foi verificada a partir de agosto nos machos e de outubro nas fêmeas. Registrou-se, tanto nos ovários quanto nos testículos, duplicação do comprimento e triplicação da largura entre a fase imatura e a reprodutiva. $\mathrm{O}$ amadurecimento sexual dos machos ocorreu dentro do sítio de hibernação. As fêmeas completaram o amadurecimento sexual mais tardiamente, quando já se encontravam fora do refúgio. O estado de desenvolvimento do aparelho reprodutor (sexualmente imaturo) e a cavidade abdominal preenchida por corpos gordurosos caracterizaram o estado de diapausa.

Palavras-chave: hibernação, percevejo-do-grão, órgãos reprodutivos. 


\section{INTRODUCTION}

Oebalus poecilus (Dallas), commonly known as the small rice stink bug, is one of the main pests of irrigated rice in Brazil (Rosseto et al., 1972; Gallo et al., 2002). In spite of its recognized economic importance, information about its bioecology, especially in the hibernation phase, is scarce. O. poecilus hibernates from March to November in Rio Grande do Sul State (Albuquerque, 1993) with three distinct hibernation periods: stay (March to November), departure (November to December), and residual (December to February) (Santos et al., 2001).

Few studies deal with physiological age grading based upon internal reproductive organ characteristics and of body fat amount contained in the abdominal cavity of pentatomids. Kiritani (1963) used the changes in morphological characteristics of the reproductive organs of Nezara viridula (L.) to study its population dynamics. Nilakhe (1976) observed that the hibernating females of Oebalus pugnax (F.) show atrophied ovaries and great body-fat amounts in the abdominal cavity. Silva (1988), based on the aspect of the ovaries of $O$. poecilus, identified three physiological ages: immature, mature, and post-reproductive. Aner (1991) established different physiological ages for females of Tibraca limbativentris Stal through the characteristics of the reproductive organs, gastric caeca, and the body fat amount. More recently, Mourão \& Panizzi (2000, 2002) characterized the diapause and the different morphological types of the neotropical brown stink bug Euschistus heros (F.).

The present study was conducted to describe the development of the internal reproductive organs of $O$. poecilus, as well as to evaluate the body fat amount contained in the abdominal cavity during hibernation.

\section{MATERIALS AND METHODS}

Adults of $O$. poecilus were sampled in bamboo (Bambusa tuldoides Munro) (Gramineae) litter in an approximately $140 \mathrm{~m}^{2}$ area in Eldorado do Sul (30 $02 ' \mathrm{~S}$ and $\left.51^{\circ} 23^{\prime} \mathrm{W}\right)$, RS, from June 2000 to December 2001. Fifty-six sampling units, each with $300 \mathrm{~cm}^{2}$ of litter, were taken randomly at weekly or fortnightly intervals totaling 55 sampling occasions. In the laboratory, the bugs were taken from the litter and counted. Of the sampled individuals, $40 \%$ were dissected on every occasion, totaling 707 females and 695 males. The insects were killed with ethyl acetate fumes and dissected in $70 \%$ ethyl alcohol under a stereomicroscope. The developmental state of the internal reproductive organs (immature or mature) was recorded. Measurements (length and width) of ovaries, lateral oviducts, common oviduct, and spermatheca, in females, and the testis, vas deferens, and ejaculatory bulb, in males were taken with a micrometric eyepiece coupled to the stereomicroscope. Illustrations of the internal reproductive organs are presented.

The body fat amount present in the abdominal cavity of females and males was evaluated according to the proportion of the cavity that was filled: $1=$ one third; $2=$ two thirds; $3=$ three thirds.

During the period of refuge abandonment (November to December) adults were sampled in the spontaneous vegetation, $3 \mathrm{~m}$ from the hibernation site, on 8 occasions. A sweep net (30 cm diameter) was utilized (one stroke/m) totaling 140 strokes/ sample. The individuals captured were dissected to compare their reproductive state and body fat amount with those of adults collected from the bamboo litter.

The data were statistically analyzed by SAS software using the $f$ and Tukey test $(p<0.05)$ for comparison of means.

\section{RESULTS AND DISCUSSION}

\section{Female internal reproductive organs (Fig. 1)}

There are seven ovarioles per ovary. Pendergrast (1957) pointed to seven as the most common number of ovarioles found in Heteroptera such as T. limbativentris (Aner, 1991), Nazeeriana sindellus (Kamaluddin \& Ahmad, 1992), and Scotinophora limosa (Walker) (Mohammad et al., 1994). The ovarioles are of the meroistic telotrophic type (Chapman, 1985). At the apex of each ovariole is a terminal filament joined to the others of the same ovary, forming a single suspensory ligament per ovary which attaches to the body wall. Each ovariole opens through a pedicel in its respective lateral oviduct. The lateral oviducts join in their distal region, beginning the common oviduct. In the lateral-common oviduct junction is a ring of microvillosities. A pear-shaped spermatheca stands between the lateral oviducts; on its extremity a ductus receptaculi joins it to a gland.

In the immature female (Fig. 1A), the reproductive organs are frail and almost totally translucent, occupying a small portion of the insect abdominal cavity, which was also reported for other species of pentatomids (Kiritani, 1963; Nilakhe, 1976; 
Silva, 1988). The ovaries are minute, coalescent, and wrapped in a mesh of tracheoles making them difficult to see. Ovary length averages twice its width; in the lateral oviduct, this ratio is $6 \mathrm{x}$, and in the common oviduct, it is two thirds (Table 1). The common and lateral oviducts are translucent with coalescent walls. The spermatheca is an average of 3.5 times longer than wide (Table 1), translucent and flattened, and its gland is inconspicuous.

In the sexually mature female (Fig. 1B), the reproductive organs are larger than those of the immature, practically filling the abdominal cavity. The ovaries become almost $2 \mathrm{x}$ as long and $3 \mathrm{x}$ as wide as those of the immature female (Table 1). The germarium-vitelarium region becomes distinct due to the presence of oocytes in different developmental stages. The oocytes show different coloration according to their developmental stage, varying from milky white to a light green color. The lateral oviducts, on average, diminish 1/3 in length and double in width (Table 1), due to the presence of oocytes, with generally two of them in each oviduct. The common oviduct enlarges approximately 1/3 in length (Table 1). In both structures, the increase in overall volume is associated with oocyte passage. The spermatheca becomes ovoid but does not vary in size (Table 1). The spermatheca gland increases in volume and becomes milky white as does the ductus receptaculi.
Females show a small increase in ovary size during their stay in the hibernation site. The increase of male internal reproductive structures occurs during the hibernation period (Fig. 2). The largest variations $(p>0.05)$ in size were observed in females in the spontaneous vegetation when compared to those sampled in the hibernation site, which occurred starting in the second week of November. Developing oocytes were also observed in females sampled outside the hibernation site, suggesting that female sexual maturation occurs at this site.

\section{Male reproductive internal organs (Fig. 3)}

Testes are long, ovoid, and orange. Each testis consists of seven follicles. After the testis lies a seminal vesicle practically indistinct from the vas deferens, which is long and slender, with an orange color similar to that of the testis. There is an accessory gland (mesadenia type), sack-shaped and milky white, which wraps each vas deferens in its distal region, before the junction with the ejaculatory bulb. The ejaculatory bulb is balloon-shaped and dorsally covered by an irregularly shaped accessory gland. These structures comprising the male reproductive system have been described for other pentatomids such as $N$. sindellus (Kamaluddin \& Ahmad, 1992) and S. limosa (Mohammad et al., 1994).

TABLE 1

Average values of length and width $(\mathrm{cm})$ of reproductive system structures, immature and reproductive, of male and female of Oebalus poecilus (average $\pm \mathrm{SE}$; $n$. of measures).

\begin{tabular}{|c|c|c|c|c|c|c|c|}
\hline \multirow{2}{*}{ Structure } & \multicolumn{3}{|c|}{ Immature } & \multicolumn{4}{|c|}{ Mature } \\
\hline & \multicolumn{2}{|c|}{ Length (n) } & Width (n) & \multicolumn{2}{|l|}{ Length (n) } & \multicolumn{2}{|l|}{ Width (n) } \\
\hline Ovary & $0.12 \pm 0.001$ & (153) & $0.06 \pm 0.001$ & $0.23 \pm 0.007$ & (24) & $0.18 \pm 0.008$ & (24) \\
\hline Lateral oviduct & $0.06 \pm 0.001$ & (79) & $0.01 \pm 2 \times 10^{-4}$ & $0.04 \pm 0.002$ & (16) & $0.02 \pm 0.001$ & (16) \\
\hline Common oviduct & $0.02 \pm 4.8 \times 10$ & (79) & $0.03 \pm 5.6 \times 10^{-4}(79)$ & $0.03 \pm 0.001$ & (15) & $0.03 \pm 0.002$ & (15) \\
\hline Spermatheca & $0.07 \pm 8.8 \times 10$ & (69) & $0.02 \pm 5.6 \times 10^{-4}(69)$ & $0.07 \pm 0.002$ & (17) & $0.02 \pm 0.001$ & (17) \\
\hline Testis & $0.04 \pm 4.7 \times 10$ & $(170)$ & $0.06 \pm 6.6 \times 10^{-4}(170)$ & $0.08 \pm 0.001$ & (29) & $0.16 \pm 0.002$ & (29) \\
\hline Vas deferens & $0.12 \pm 0.002$ & (85) & $0.01 \pm 2.3 \times 10^{-4}(85)$ & $0.09 \pm 0.004$ & (14) & $0.01 \pm 5.7 \times 10^{-4}$ & (14) \\
\hline Ejaculatory bulb & $0.04 \pm 4.6 \times 10^{-}$ & (84) & $0.04 \pm 4.5 \times 10^{-4}$ & $0.03 \pm 1.8 \times 10^{-4}$ & (15) & $0.03 \pm 5.1 \times 10^{-4}$ & (15) \\
\hline
\end{tabular}



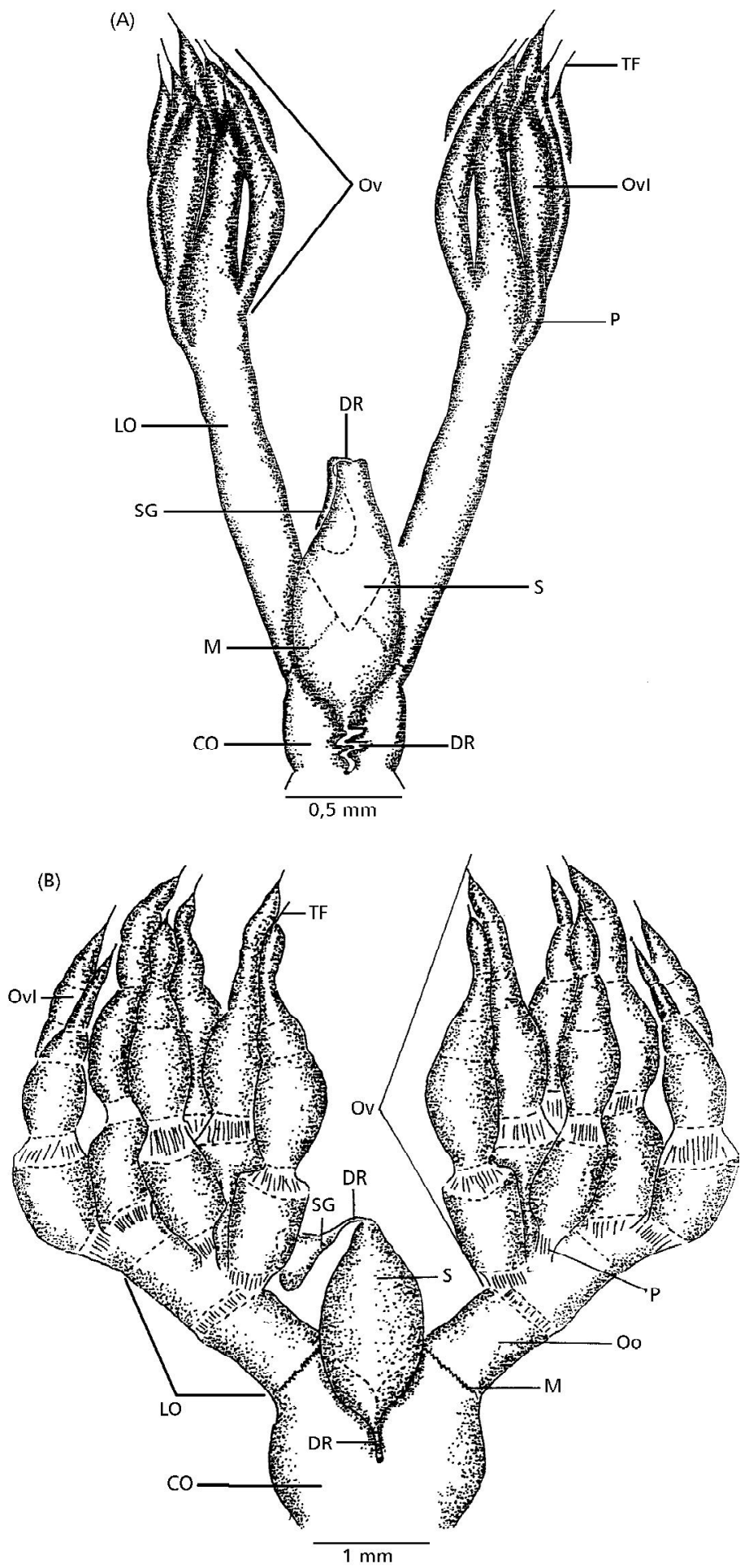

Fig. 1 - Internal reproductive organs of a sexually immature female of Oebalus poecilus (Dallas) (A), and sexually mature (B), dorsal view. CO, common oviduct; DR, ductus receptaculi; LO, lateral oviduct; M, microvillosities; Oo, oocyte; Ov, ovary; Ovl, ovariole; P, pedicel; S, spermatheca; SG, spermathecal gland; TF, terminal filament. 
In sexually immature males (Fig. 3A), the reproductive system is small and occupies only a minor part of the abdominal cavity. The testes are very small, $1.5 \mathrm{x}$ wider than long (Table 1). They are covered by innumerable tracheoles and body fat. The mesadenia is milky white and the accessory gland is transparent. The orange coloration of the testis, seminal vesicles, and vasa deferentia facilities their visualization in the abdominal cavity. The vasa deferentia averages $12 \times$ longer than wide. The ejaculatory bulb measures the same in both dimensions (Table 1).

The sexually mature reproductive organs (Fig. 3B) are larger than those of the immature and occupy more than $2 / 3$ of the insect abdominal cavity. The testes double in length and almost triples in width (Table 1), this increase representing the principal distinctive characteristic between sexually immature and mature individuals. The vasa deferentia decreases about $1 / 4$ in length but retains the same width while the ejaculatory bulb decreases $1 / 4$ in both.

During the hibernation period, a progressive increase in both dimensions of the testes was observed, noticeable from the $1^{\text {st }}$ week of October until December (Fig. 2B). From the second fortnight of November, no statistical difference $(p<0.05)$ was verified between the measurements of males collected in or outside the hibernation site. These results suggest that male sexual maturation occurs inside the hibernation site.

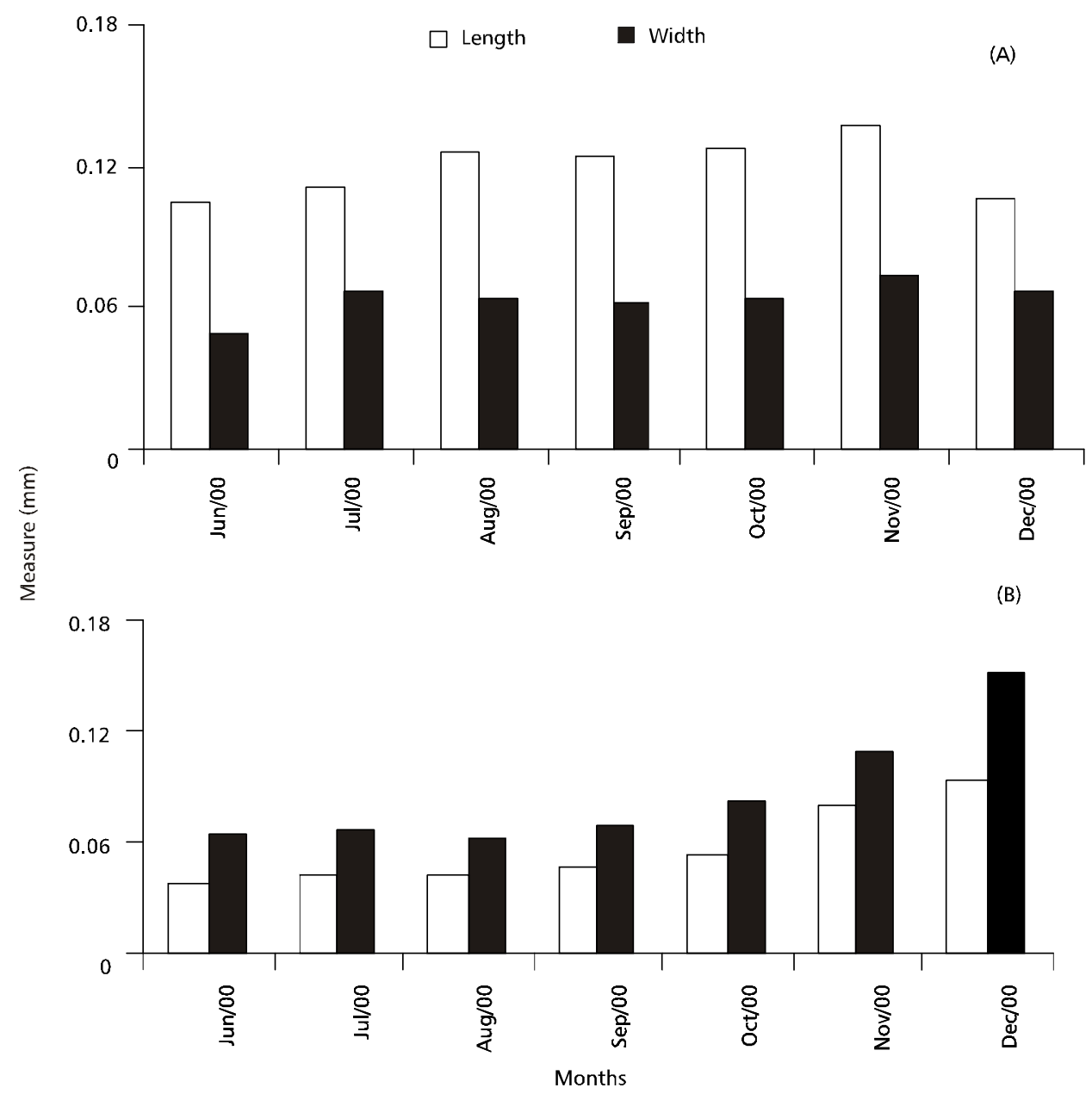

Fig. 2 - Average ovary length and width measurements (A), and those of testes (B) of Oebalus poecilus during the hibernation period (July to December, 2000). 


\section{Diapause characterization}

The monthly percentage of males and females of $O$. poecilus for each of the three categories of body fat levels is shown in Fig. 4A and B, respectively. The abdominal cavity of both males and females was more than $2 / 3$ filled with fat body at the beginning of the refuge invasion period (March). The storage of reserve substances, such as fat body, before arrival at the hibernation site, has already been pointed out by Beck (1980) and Tauber et al. (1986). Radjabi (1995) found that adults of Eurygaster integriceps Put. are $2 \mathrm{x}$ heavier at the time of arrival than on abandoning the refuge.

It was observed that besides the large quantity of reserves such as fat body, both males and females of $O$. poecilus invading the hibernation refuge have immature internal reproductive organs (Figs. 1A, $3 \mathrm{~A}$ and 4 ). These features characterize the imaginal reproductive diapause state in insects (Lees, 1955; Beck, 1980; Tauber et al., 1986). Kiritani (1963) utilized these characteristics to determine the diapause in N. viridula, Nilakhe (1976) for $O$. pugnax, and Aner (1991) for T. limbativentris. Mourão \& Panizzi (2000, 2002) utilized the length of the pronotal spine to characterize the diapause in E. heros. They verified that females with immature reproductive organs usually had shorter pronotal spines when compared to those with mature ones. Albuquerque (1993) also showed that diapausing morphs of $O$. poecilus presented lesser development of the lateral angles of the pronotum, and immature reproductive organs.

It is valid to assume that $O$. poecilus remain in imaginal reproductive diapause from middle March until the end of October. These results corroborate those of Amaral (1949), who found in the laboratory that adult small rice stink bugs are inactive during winter, copulating only at the end of October, and beginning reproductive activity in the $1^{\text {st }}$ week in November.

As to body fat for males (August) and females (October), the percentage of individuals in levels one and two begins to increase, mostly for males
(Fig. 4). These results indicate that there is pronounced energy consumption as the time for refuge abandonment approaches in early November (Santos et al., 2001). This is probably associated with the internal reproductive organ maturation and flight activity. Radjabi (1995) verified an average $25 \%$ weight reduction in individuals of $E$. integriceps between the beginning and the end of their hibernation period. Mourão \& Panizzi (2000) found a large number of mature females $E$. heros in the period from March to November, when the insects were feeding on soybean and sunflower plants outside the hibernation refuges.

Associating the obtained fat body results to the changes observed in the reproductive organ development of $O$. poecilus, the reserve substances are not necessary to promote complete sexual maturation, mainly oocyte production. This process involves a large metabolic cost demanding intense storage of energy and nutrients (Parra, 1991). Therefore, it seems that females have to search for food in order to promote the ripening of the ovaries, after abandoning the hibernation site. In males, reserves accumulated as fat body seem adequate to allow sexual maturation. Earlier reproductive maturation in males may be due to differences in gamete formation processes. Nijhout (1998) points out that for species with a short life cycle, there is no cyclic gamete production in males, while in females the vitelogenesis encompasses various steps, where body fat has an important role. Arrival at the hibernation refuge with the abdominal cavity filled by body fat and immature reproductive organs, which characterize imaginal reproductive diapause, allows $O$. poecilus to get through the unfavorable period, maximizing its survival.

This study, which also comprehends and characterizes the diapause, is important in interpreting of population field data and, consequently, could furnish subsidies for the integrated pest management of $O$. poecilus (TyndaleBiscoe, 1984; Aner \& Becker, 1991; Redaelli et al., 1995; Diefenbach et al., 1998). 
(A)
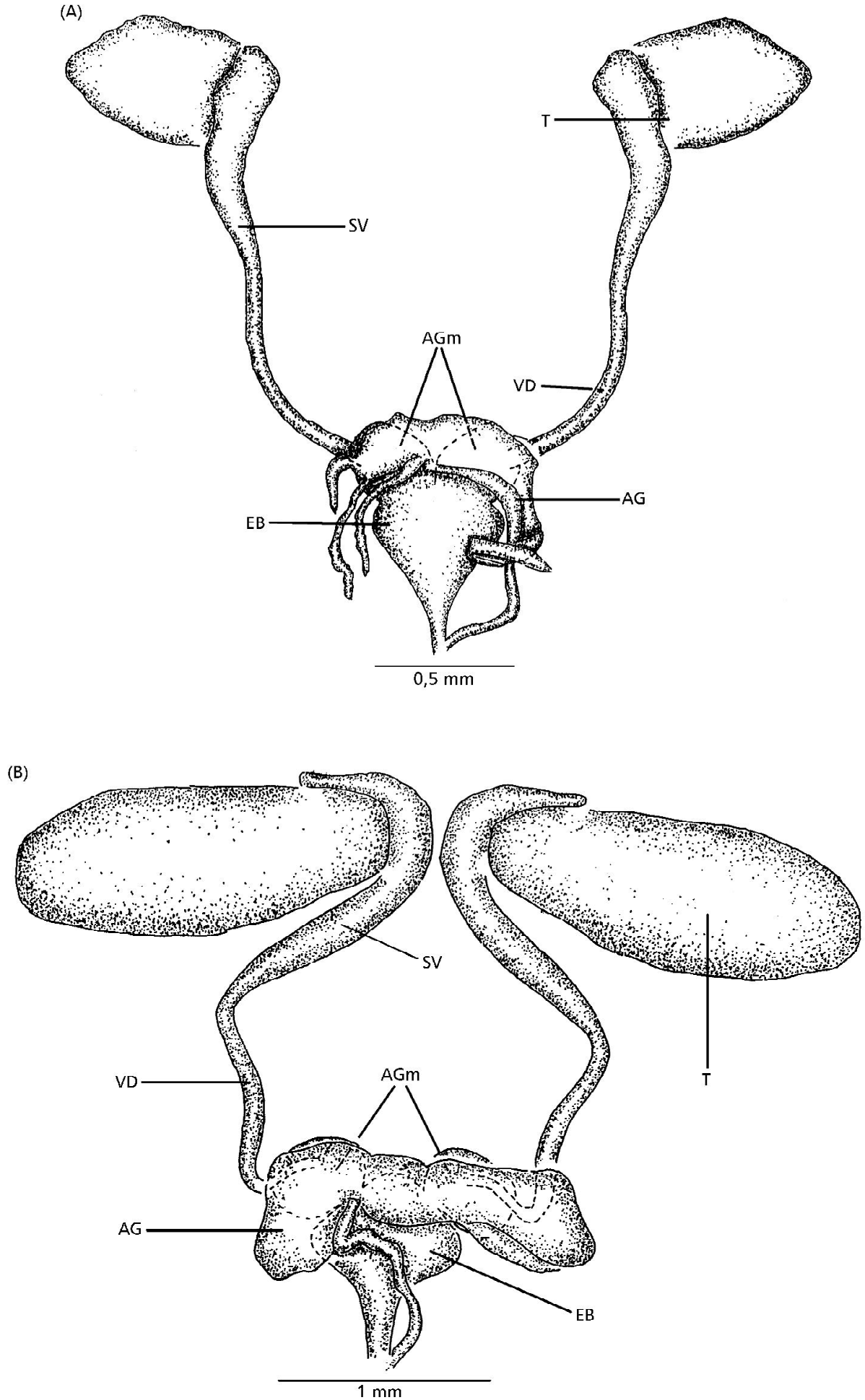

Fig. 3 - Internal reproductive organs of a sexually immature male of Oebalus poecilus (Dallas) (A), and sexually mature (B), dorsal view. AG, accessory gland; Agm, accessory gland mesadenia; EB, ejaculatory bulb; SV, seminal vesicle; T, testis; VD, vas deferens. 


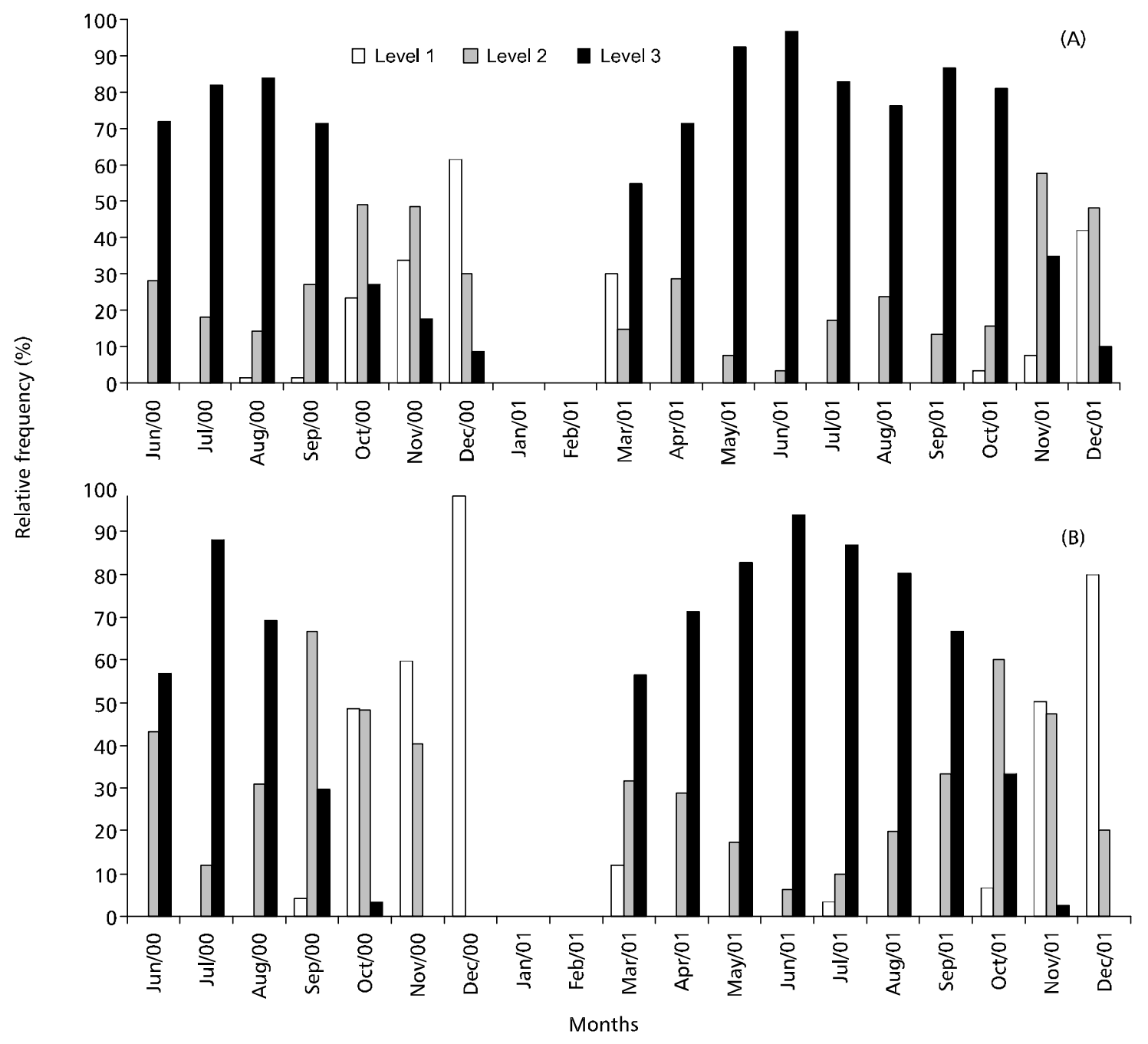

Fig. 4 - Monthly percentage of individuals of Oebalus poecilus (Dallas) at each level of body fat present in the abdominal cavity, from June 2000 to December 2001, females (A) and males (B). (1, 2, and 3 respectively indicate 1/3, 2/3, and 3/3 of the abdominal cavity filled with body fat.)

Acknowledgments - We would like to thank the Conselho Nacional de Desenvolvimento Científico e Tecnológico (CNPq), for a PhD fellowship granted to Regis S. S. dos Santos (Proc. № 140344/2000-4), and Rita de Cássia Antochevis for help in data tabulation.

\section{REFERENCES}

ALBUQUERQUE, G. S., 1993, Planting time as a tactic to manage the small rice stink bug, Oebalus poecilus (Hemiptera: Pentatomidae), in Rio Grande do Sul, Brazil. Crop. Protection., 12: 627-630.
AMARAL, S. F., 1949, Biologia e importância econômica do percevejo do arroz no estado de São Paulo. O Biológico, 15: $47-58$

ANER, U., 1991, Pentatomídeos em hibernação em touceiras de gramíneas no município de Eldorado do Sul, RS (Insecta: Heteroptera: Pentatomidae). Dissertação (Ecologia), UFRGS, Porto Alegre, RS, 116p.

ANER, U. \& BECKER, M., 1991, The internal reproductive organs and physiological age-grading in Neotropical carabids. I. Lebia concinna (Brullé, 1837) (Coleoptera: Lebiini) a predator of insect pests in Brazil. Rev. Brasil. Biol., 51: 159168. 
BECK, S. D., 1980, Insect photoperiodism. 2. ed. Academic Press, New York, 387p.

CHAPMAN, R. F., 1985, The insects structure and function. 3. ed. Hodder and Stroughton, Hong King, 919 p.

DIEFENBACH, L. M. G., REDAELLI, L. R. \& GASSEN, D. N., 1998, Characterization of the internal reproductive organs and their state as diapause indicator in Phytalus sanctipauli Blanchard, 1850 (Coleoptera: Scarabaeidae). Rev. Brasil. Biol., 58: 541-546.

GALLO, D. (in memoriam), NAKANO, O., NETO, S., S., CARVALHO, R. P. L., BAPTISTA, G. C., BERTI FILHO, E., PARRA, J. R. P., ZUCCHI, R. A., ALVES, S. B., VENDRAMIM, J. D., MARCHINI, L. C., LOPES, J. R. S. \& OMOTO, C., 2002, Entomologia agrícola. FEALQ, Piracicaba, 920p.

KAMALUDDIN, S. \& AHMAD, I., 1992, Internal anatomy and histology of alimentary organs, salivary apparatus and reproductive organs of Megarrhamphini, Phyllocephalini and Tetrodini (Hemiptera: Pentatomidae: Phillocephalinae) and their bearing on classification. Philipp. J. Sci., 121: 129-156.

KIRITANI, K., 1963, The change in reproductive system of the southern green stink bug, Nezara viridula, and its application to forecasting of the seasonal history. Jap. Jour. Appl. Ent. Zool., 7: 327-337.

LEES, A. D., 1955, The physiology of diapause in arthropods. Cambridge University Press, London, 151p.

MOHAMMAD, F. A., AHMAD, I. \& NAQVI, S. N. H., 1994, Some aspects of internal anatomy of the rice black bug Scotinophara limosa (Walker) (Hemiptera: Pentatomidae) with reference to its cladistic relationships. Pakistan J. Zool., 26: $257-260$.

MOURÃO, A. P. M. \& PANIZZI, A. R., 2000, Diapausa e diferentes formas sazonais em Euschistus heros (Fabr.) (Hemiptera: Pentatomidae) no norte do Paraná. An. Soc. Entomol. Brasil, 29: 205-218.

MOURÃO, A. P. M. \& PANIZZI, A. R., 2002, Photophase influence on the reproductive diapause, seasonal morphs, and feeding activity of Euschistus heros (Fabr., 1798) (Hemiptera: Pentatomidae). Braz. J. Biol., 62: 231-238.

NIJHOUT, H. F., 1998, Insect hormones. 3. ed. Princeton University Press, New Jersey, 267p.
NILAKHE, S. S., 1976, Overwintering, survival, fecundity, and mating behavior of the rice stink bug. Ann. Entomol. Soc. Am., 69: 717-720.

PARRA, J. R. P., 1991, Consumo e utilização de alimentos por insetos, pp. 9-65. In: A. R. Panizzi \& J. R. P. Parra (eds.), Ecologia nutricional de insetos e suas implicações no manejo integrado de pragas. Manole, São Paulo, SP, 359 p.

PENDERGRAST, J. G., 1957, Studies on the reproductive organs of the Heteroptera with a consideration of their bearing on classification. Trans. R. Ent. Soc. London., 109: 1-63.

RADJABI, G. H., 1995, Trend of body weight variations of Eurygaster integriceps Put. in the fields and at high altitudes. Appl. Entomol. and Phytopathol., 62: 15-16.

REDAELLI, L. R., BECKER, M. \& ROMANOWSKI, H. P., 1995, Changes in the internal reproductive organs and body fat levels as diapause indicators in Oryzophagus oryzae (Costa Lima, 1936) (Coleoptera: Curculionidae). Rev. Brasil. Biol., 55: 737-744.

ROSSETTO, C. J., SILVEIRA NETO, S., LINK, D., GRAZIAVIEIRA, J., AMANTE, E., SOUZA, D. M., BANZATTO, N. V. \& OLIVEIRA, A. M., 1972, Pragas do arroz no Brasil, pp. 149-238. In: Reunião do Comitê de Arroz para as Américas, 2., Min. Agric., Dep. Nac. Pesq. Agropec., Div. Pesq. Fitotécn., Brasília, DF.

SANTOS, R. S. S., REDAELLI, L. R., DIEFENBACH, L. M. G., PRANDO, H. F. \& ROMANOWSKI, H. P., 2001, Destino de uma população hibernante de Oebalus poecilus (Dallas) (Hemiptera: Pentatomidae). In: Congresso Brasileiro de Arroz Irrigado, 2., Anais... Irga, Porto Alegre, RS, pp. 415-418.

SILVA, C. P., 1988, Fecundidade, longevidade e sucesso no estágio de ovo de Oebalus poecilus (Dallas, 1851) (Heteroptera: Pentatomidae) em condições de laboratório e sucesso do estágio de ovo em cultura de arroz irrigado (Oryza sativa L.). Dissertação de Mestrado (Ecologia), UFRGS, Porto Alegre, RS, 123p.

TAUBER, M. J., TAUBER, C. A. \& MASAKI, S., 1986, Seasonal adaptations of insects. Oxford University Press, New York, 411p.

TYNDALE-BISCOE, M., 1984, Age-grading methods in adult insects: a review. Bull. Entomol. Res., 74: 341-377. 